\title{
THE LAST PROPHET OF THE OLD TESTAMENT
}

\author{
Prof. Ph.D. Mihail TEODORESCU, \\ Faculty of Theology and Sciences of Education, Valahia University of Târgoviște, \\ ROMANIA \\ E-mail: teodorescu_mhl@yahoo.com
}

\begin{abstract}
The prophets of the Old Testament end with John the Baptist, The Forerunner of God, declared to be "the greatest man among those born from women". His spiritual elevation is impressive, because he cumulates in himself the revolutionary effort of all the prophets, in a life loved entirely in the devotion of the noble cause for which he was born. His message which recalls the necessity for spiritual renewal for the human soul is always valid.
\end{abstract}

Keywords: sin; awareness; redemption; purification; renewal;

\section{INTRODUCTION}

The supernatural Revelation of the Old Testament belongs, as an initiative, to the providential work of God, through which He picked the humans, on the basis of His foreseeing knowledge (Jer. 1, 5), to fulfill concrete tasks. These humans would act through deeds (individual, or catalyzing entire masses, like Moses, or the Judges), or would speak in the name of Yahve, to express in a complex way the divine will. Chosen people always have significant names, which express the essence of the mission they have assumed. ${ }^{1}$

The trail of the prophets is partially known, as the books of the Old Testament have managed to record personalities and deeds, along with the preservation of the prophetic writings themselves. At the same time, we can evaluate in a broad picture, the prophetic message of the Old Testament, to discover and underline their essential mission, beyond just the conservation struggle of the Jewish people in the boundaries of the revelated monotheism, which is the messianic mission, to announce the One that was about to come for the salvation of the world. From a Christian perspective, this is the main message of the prophets of the Old Testament, their kind historically ending which the Incarnation of Messiah, God's anointed One, the last prophet of the Old Testament ${ }^{2}$, St. John the Baptist literally presenting Him to the world.

\section{THE BIRTH OF THE FORERUNNER, A DIVINE WORK}

Born from a priestly family, from Zachariah and Elisabeth, St. John the Baptist represents the complete character of the prophet, bypassing in his spiritual stature even the elegant greatness of Isaiah, the self-sacrifice of Jeremiah, the dynamic and all the way up to obscurity vision of Ezekiel, and even the time-piercing power of Daniel. This comparison is valid because it is fundamented on Christ's appreciation of John, when He declares him, in an admirative way, to be "the greatest" man, among those "born from women" (Mt. 11, 11).

The events that gravitated around the birth of St. John are known due to Luke the Evangelist, he himself being a soul caught in the net of divine revelations to present to the

\footnotetext{
${ }^{1}$ Studiul Vechiului Testament, pentru Institutele teologice, Ed. IBMBOR, București, 1983, pp. 222, 234, 245

${ }^{2}$ Pr. Prof. Dr. Ioan Bria, Dicționar de Teologie Ortodoxă, Ed. IBMBOR, București, 1994, p. 287
} 
world the Mystery of its salvation. The first event in his work is the majestic and convincing apparition of archangel Gabriel in the Holy of the temple, before the priest Zachariah, who entered that area through drawing lots, which, in the religious atmosphere of the Old Testament, would always mean the expression of the divine will. ${ }^{3}$ Called to a special service, Zachariah (whose name means "God remembers", signifying the divine appreciation regarding virtues and consistent prayer), receives the news of the birth of his only son and the name that he needs to bear, John, which is also very significant. "God showed mercy" could refer to the fulfilling of a lifetime prayers for the birth of this child, but it applies more to the divine plan of the world's salvation that needs to contain a certain development of events, which imply the participation of a forerunner of Messiah. From just and pure parents before God, a holy man is about to be borne, whose life will not bring joy just to his family, but to an entire people through which they will return to "their Lord God". This holy man will be "armed" with the "spirit and power of Elijah", to fulfill his mission, which was to bring the heart to its fundamental vocation, the awakening of love that unites the humans and guides them to the love among them and towards God (Luke 1, 15-17).

The conception of the Forerunner in the womb of Elisabeth's remains a mystery until the time when the child's conception could not be hidden anymore. At the fulfilling of the nine months, Elisabeth gives birth to John, and in the $8^{\text {th }}$ day, in the presence of relatives and friends, the circumcision ritual takes place (Genesis 17, 23; Exodus 4, 25). The general intention to name the child after his father, Zachariah, as an underlining of God's love, Who remembers the prayers of the His just ones, is discarded by the parents who are consequent to the instructions of archangel Gabriel. John would be his name, through which it is showed God's mercy towards the childless parents' prayers, but also His mercy towards humankind who was lost the sin's darkness. The birth of the Forerunner is directly tied to the recently incarnation of the One who he will announce, the One who will fulfill all, the Savior Jesus Christ. The confirmation of the name by the priest Zachariah, acknowledges the validity of the angelic prophecy, lifting the punishment bestowed upon him. He is able to speak again, praising and blessing God, and Zachariah is fulfilled with the Holy Spirit and prophesizes. His words bring praise and blessings to God, Who searched His people and redeemed him, as He announced it through His prophets. Through an heir of David's house He gave the power of salvation to the human against his enemy, death. This salvation takes place through God's mercy towards the humans, fulfilling His promise to Abraham, the father of the Jewish people. And all of these were done so that the humans, cleansed by sins, to be able to serve God in holiness and justice during all their lives. As for his son, John, he will be the prophet of The Most High One, walking before the face of God to prepare His way. The preparation of the Jewish people takes place through the warning regarding the imminence of salvation, salvation which is gained only through the forgives of the sins by the Sunrise from above. This Person, who searched the humans through mercy, wishes to enlighten those who stay in the dark and in the shadow of death and to set straight the steps of humans on the path of their reconciliation with God (Luke 1, 67-80).

The childhood of St. John will develop under the handprint of the providential work of the Holy Spirit, but also due to the fact that the child grew in a house of prayer and of

\footnotetext{
${ }^{3}$ Pr. Prof. Dr. Dumitru Abrudan, Diac. Prof. Dr. Emilian Cornițescu, Arheologie biblică, Ed. IBMBOR, București, 1994, pp. 152, 242

${ }^{4}$ Pr. Dr. Ioan Mircea, Dicționar al Noului Testament, Ed. IBMBOR, București, 1995, p. 573

${ }^{5}$ Ibidem, p. 228
} 
Gods, being circumcised and dedicated to God. ${ }^{6}$ His definitive formation will take place through his life in the desert until the day he will show himself to Israel, that is until the beginning of his mission, a period of time spent in meditation and prayer, away from the temptations which often overwhelm, in the social community, most young people. His school was prayer, meditation, the Law, the Prophets and the divine Revelation.

\section{THE MISSION OF THE FORERUNNER}

When the time came, God called John from meditation and prayer to preaching, "in the fifteenth year of the rule of the Cezar Tiberius, when Pilat from Pont was the prosecutor of Judaea, Herod, the tetrarch of Abilene, in the days of hierarchs Anna and Caiafa" (Luke $3,1-2)$. The $15^{\text {th }}$ year of rule of the roman emperor Tiberius would correspond approximatively to the year 26 A.D., this being the first year from the ten years of governing of Pilat from Pontus in Judaea (26-36 A.D.). ${ }^{7}$

The people were impressed by this public appearance, because the image of the Forerunner was touching the people's souls, expressing sincerity and total devotion to his assumed cause. His clothes and food were austere, but fit for his prophetic mission. The camel hair had a rough fabric, rigid, a cloth wore by poor people, or by those who were mourning and repenting. ${ }^{8}$ Such a cloth St. John wore, having a lather belt around his hips. Locusts and wild honey was his usual food. This image was hiding although a great spiritual force, because, when St. John left the desert to preach, he spoke "with the spirit and power of Elijah" (Luke 1, 17; Mark 1, 6). Being called by God at this service, John was a forerunning beacon of the true Light, a morning star which announced the sunrise, a voice, an exclamation, a call before clear and explicit words ${ }^{9}$ that Messiah was about to say.

His call said: "Redeem yourselves because the Kingdom of God is upon us!" (Mt. 3, 2). With this message the Savior Christ will begin His public activity which His Forerunner prepared for Him (Mt. 4, 17). The meaning of this urge is the following: the compulsion of one's own conscience investigation, the awareness and recognition of one's sins, the decision to not sin anymore, the fight against temptations and sins, the preparation for a life in God. ${ }^{10}$

The mission, activity, and role that St. John the Baptist had to fulfill were part of the salvation plan of humankind. That is why two prophets of the Old Testament had the vision of his mission, speaking about him way before his time. The prophet Malachi announced the existence of the Forerunner, who would have an angelic life and service: "See, I am sending my messenger to prepare the way before me, and the Lord whom you seek will suddenly come to his temple. The messenger of the covenant in whom you delight - indeed, he is coming, says the Lord of hosts" (Malachi 3, 1).

And the prophet Isaiah will underline the content of his preaching, with the desired and expected spiritual transformations in the souls of his listeners. "A voice cries out: "In the wilderness prepare the way of the Lord, make straight in the desert a highway for our God. Every valley shall be lifted up, and every mountain and hill be made low; the uneven ground shall become level, and the rough places a plain. Then the glory of the Lord shall be revealed, and all people shall see it together, for the mouth of the Lord has

\footnotetext{
${ }^{6}$ Pr. Prof. Dr. Dumitru Stăniloae, Teologia Dogmatică Ortodoxă, Vol. III, Ed. IBMBOR, București, 1997, p. 45

7 Pr. prof. dr. Vasile Mihoc, Lect. dr. Daniel Mihoc, Pr. asist. Ioan Mihoc, Introducere în studiul Noului Testament, Curs pentru anul I, Sibiu, 2007, p. 65

${ }^{8}$ Pr. Prof. Dr. Dumitru Abrudan, Diac. Prof. Dr. Emilian Cornițescu, op. cit., pp. 119, 143

${ }^{9}$ Sf. Chiril al Alexandriei, Comentar la evanghelia după Luca, Ed. Pelerinul Român, Oradea, 1998, p. 30

${ }^{10}$ Pr. Dr. Ioan Mircea, op. cit., p. 406-407
} 
spoken." (40, 3-5). This prophecy contains also an atemporal message and wordy of following it for whoever wishes salvation, because the spiritual transformations which will come into the world, although they seem imminent in the time of Isaiah, will be fulfilled centuries later in the time of John the Baptist, who preached to the people in a time when the Saviour didn't show himself to the world (Luke 3, 4-6).

\section{THE SERMON OF SF. JOHN THE BAPTIST}

So, the voce of John was calling in the Judea's desert: "The voice of one crying out in the wilderness: 'Prepare the way of the Lord, make his paths straight. Every valley shall be filled, and every mountain and hill shall be made low, and the crooked shall be made straight, and the rough ways made smooth; and all flesh shall see the salvation of God." (Luke 3, 4-6). The stated command: "Prepare the way of the Lord" means: "prepare for receiving the commands which Christ will give. Make it stop all the symbols, figures and types, stop thinking about the crooked!". The symbolism of the words is evident, the "way" representing the direction through which the human being go to physically, but most of all spiritually, a language found in the Old Testament at Isaiah: "the way of the righteous is level; O Just One, you make smooth the path of the righteous" $(26,7)$.

The way can lead to evil if it is winding, because the objectives of evil are deceitful and changing, offering a temporal good, perishable, which belongs only to this life. The way that leads to good is always straight, coherent, having a well defined and stable goal, which is the Kingdom of Heavens. This way is easy to walk on for the human consequent to his spiritual aspirations, being helped continuously also by God through His grace. The transformation is appropriate for the soul, which was made bun and fare by God. Removing the slag of sins, the soul renews his spiritual powers, being reinforced through the grace. Sinners, however, have crooked ways and twisted paths, wishing always something else, but always from the perishable ones (Wisdom 2,15).

Deep walleyes and angulous peeks from the path of the human, mentioned in the prophecy, are understood as the spiritual obstacles. These will be made smooth through the destruction of the sin in the body of the humans, due to the redeeming sacrifice of Jesus Christ, Who killed in the body the law of sin. "The devil being removed, the way towards salvation is much more easier". "At the same time, the possibility of salvation is offered to all humans, not just to the Jews, because "all the nations you have made shall come and bow down before you, O Lord" (Psalm 86, 9).

St. Theofilact of Bulgaria (1004-1107 A.D.) ${ }^{13}$ interprets in this way the sermon of St. John the Baptist: "The way of the Lord is the Gospel, the New Law, and the twisted ways the commands of the Old Law. So, it says: be ready for the evangelic joy, and he commands of the Law make them smooth, that is spiritual, because the Spirit is smooth. So, when you will see the Jews that physically they understand the Law, then you will understand that they have not made the ways smooth, that is they do not understand the spiritual Law". ${ }^{14}$

Sf. John is called an angel, in the sense of his dispatch from God (John 1, 6), which offers him absolute credibility, not being anything humanly in his words, but the teaching of the One who sent him, and he is the emissary that delivers the news. ${ }^{15}$ As the spiritual group of the angels who serve God, which through their immaterial nature don't care about

\footnotetext{
${ }^{11}$ Sf. Chiril al Alexandriei, op. cit., p. 30

${ }^{12}$ Ibidem, p. 32

${ }^{13}$ Pr. Prof. Dr. Ioan Bria, op. cit., p. 381

${ }^{14}$ Sf. Teofilact al Bulgariei, Tâlcuirea Sf. Evanghelii de la Matei și Marcu, Ed. Sofia, 1998, p. 24

${ }^{15}$ Sf. Ioan Gură de Aur, Comentar la Evanghelia de la Ioan, Ed. Pelerinul Român, Oradea, 1997, p. 77
} 
anything organic, bodily, so does John the Baptist dedicate himself soul and body to the mission entrusted to him. His body doesn't have value, that is why he eats whatever is offered to him, and dresses with what he can, a rough cloth, cheap and uncomfortable, which doesn't protect him from the cold of the night and scorching heat of the day. ${ }^{16}$ His preaching focuses on the imminence of the establishment of the Kingdom of heavens, establishment which is imminent as the interval of time necessary for an axe to hit a tree (Mt. 3, 10), which delays the spiritual joy, in order to attract attention to the divine judgement and wrath that will show up on the Day of the $\operatorname{Lord}^{17}$ (Mt. 3, 7, 10, 12), of which no one can be absolved, not even due to their membership to Abraham's kind (Mt. 3, 9).

The necessity for redemption was determined by the imminent arrival of a Person of great importance. That is why, any pride had to be discarded so that the human can be aware of his sins, and so, repenting, he could meet Messiah. The Kingdom of heavens is offered in this life as a road and objective that needs to be pursued. The beginning of this road is here, by the receipt of the earnest of the future goods, and those who walk on this road, gaining through grace, good deeds and spiritual purity, reach its end which is in heavens.

But the voice of John the Baptist also knew to rebuke painfully, because not all who sought him were ready to receive the redemption baptism. The Old Law prescribed Levitical cleansings in case of impurity, but without indicating the interior spiritual aspects necessary for real purification (Leviticus 14, 8; 15, 5-8; 16, 24). The Pharisees and Sadducees, but also certain people who were not willing to change their lives (Luke 3,7), driven by the general enthusiasm of John's listeners, or by their own hypocrisy, were trying to not appear below those preoccupied by spirituality. That is why, they also come to be baptised, but are rejected with heavy words: "You brood of vipers! Who warned you to flee from the wrath to come? Bear fruit worthy of repentance. Do not presume to say to yourselves, 'We have Abraham as our ancestor'; for I tell you, God is able from these stones to raise up children to Abraham. Even now the axe is lying at the root of the trees; every tree therefore that does not bear good fruit is cut down and thrown into the fire" (Mt. 3, 7-10).

St, John the Baptist reproves them with harshness knowing their short-mindness and hypocrisy. The fruits of redemption are the just and good deed, which does not bring offence to one's close one, the awareness of sins and the desire to repent, the spiritualization of the relation between the human and God. Pride cannot be useful, and it is also more in vain if it is substantiated on a genealogical descendance from someone who earned merits due to his own virtues. The Jews, but most of all Pharisees and the Sadducees, in their pride, were often pointing out that the Jewish people has as parent Abraham, who became worthy of the promise that his heirs would have many descendants, and the protection of God (Gen. 15, 6). His descendants are the heirs to the promise that was given to him. But, if Abraham, due to his faith that was considered just in the eyes of God (Rom. 4, 3; Gal. 3, 6), was also named "the friend of God" (Jacob 2, 23), the same cannot be said about his descendants, who abandoned the living of the faith to empty ritualism, who will not enjoy the same reward: "Whoever commits sin is the slave of sin" (John 8, 34). That is why, St. John warms them through the axe that is ready at the roots of the unfruitful trees, about the danger of God's wrath ready to punish evil.

The preaching activity of St. John is not confined just to the preaching of redemption. St. Evangelist Luke presents also other teachings of St. John addressed to the crowds:

\footnotetext{
${ }^{16}$ Pr. Prof. Dr. Dumitru Abrudan, Diac. Prof. Dr. Emilian Cornițescu, op. cit., p. 58

17 Xavier Leon-Dufour, Vocabular de Teologie Biblică, Ed. Arhiepiscopiei Romano-Catolice de București, 2001, p. 554
} 
"Whoever has two coats must share with anyone who has none; and whoever has food must do likewise" (Luke 3, 11). This indicates the importance of mercy, which constitutes the key to harmony among people. ${ }^{18}$ His advice continue, being addressed to tax collectors and soldiers. Those who gather taxes he advises them to not do more than what is requested of them, that is to fall into the sin of greed and love of earthly possessions, doing injustice to their own kind. Those who had the responsibility of safeguarding the public order, the soldiers who could easily recur to force abuse and constraint, having credibility in the face of the authorities, he advises them to not oppress anyone, to not be without mercy, to not accuse anyone unjustly, and to be satisfied with their payment (Luke 3, 10-14).

We notice that these advice target the development of certain virtues in the human souls, such as: mercy, the loving of one's kind, justice, fairness, honesty, humbleness. The advice seek to stimulate and develop a basis of socio-moral conduct, pursuing a spiritual transformation of the human, an awareness development of him, so that he can receive the true teaching that was about to be revealed. Pursuing such a high and new purpose than the one that the understanding of the Law provided at that time, of course repentance is not preached through the understanding of the Old Testament. Sf. John does not recommend the offering of sacrifices for sins, according to the Jewish ritual ${ }^{19}$, as it is prescribed in Leviticus $(4,27-35 ; 5,1-19 ; 6,2-7)$. He pursues the implementation of a conduct specific to the messianic time, the clearness of the mind, the heart's childhood purity, and the sharpness of the spirit, to receive the teachings that were about to be revealed. ${ }^{20}$

The advice record in the Gospel of St. Luke, the only one that presents more thoroughly the life and activity of St. John the Baptist, does not contain the full content of the sermons of St. John, but it represents them. The Evangelist confesses that St. John the Baptist was preaching the people the "good news", the Gospel (Luke 3, 18), under the form of the spiritual transformation to which the human was called, while also preaching many other things. The overwhelming personality of the last prophet of the Old Testament, the devotement of his service, the purity of his heart, his burning desire for human spiritual renewal through redemption, his lack of interest regarding the material goods, naturally arose the question among the Jewish people who was waiting for the salvation promised: "Isn't this Christ?" (Luke 3, 15). All the Evangelist confess that John never dared to use for personal gain the trust and appreciation that was showed to him, but he confessed to all that Someone else is Christ: "The one who is more powerful than I is coming after me; I am not worthy to stoop down and untie the thong of his sandals. I have baptized you with water; but he will baptize you with the Holy Spirit" (Mark 1, 7-8; Mt. 3, 11; Luke 3, 16). St. John the Baptist continues: "His winnowing fork is in his hand, and he will clear his threshing floor and will gather his wheat into the granary; but the chaff he will burn with unquenchable fire" (Mt. 3, 12; Luke 3, 17). The statement that the Saviour will baptise with "Holy Spirit and fire" does not exclude water as a matter for this Holy Mystery which will be done in the Church, because it does not refer to baptism as matter or procedure, but it refers to the effects of the Baptism Mystery, which are the total purification from sin. These words indicate also the superiority of the Christian baptism compared to the baptism that he was doing ${ }^{21}$, and for which he was preparing them for. ${ }^{22}$ The question: "Isn't he Christ?" also preoccupied the

\footnotetext{
${ }^{18}$ Pr. Dr. Ioan Mircea, op. cit., p. 315

${ }^{19}$ Pr. Prof. Dr. Dumitru Abrudan, Diac. Prof. Dr. Emilian Cornițescu, op. cit., p. 268

${ }^{20}$ Xavier Leon-Dufour, op. cit., p. 555

${ }^{21}$ Pr. Prof. Dr. Dumitru Radu, Îndrumări misionare, Ed. IBMBOR, București, 1986, p. 515

${ }^{22}$ Xavier Leon-Dufour, op. cit., p. 555
} 
religious rulers of the Jewish people from Jerusalem. They sent to him priests and Levites from among the Pharisees to get a clear answer, from John himself. St. Evangelist John, who before he became an apprentice of Christ, was an apprentice of John the Baptist (John 1, 35), probably witnessed this dialogue. That is why he presents it with accuracy, highlighting the insistences of the Pharisees: "who are you? So that we can give an answer to those who sent us" (John 1, 22).

Understanding that those who were asking him were seeking to identify him with Messiah, John the Baptist confesses openly that he is not Christ, nor Elijah (an old belief, based on the text from Malachi 3, 23, which stated that this prophet, resurrected, will activate before Messiah), nor the prophet that Moses spoke about (Deut. 18, 15). John is an unclear call that comes before the enlightening word. He is the stuttering voice of the Old Law, which does not enlighten fully like the law what brings salvation. ${ }^{23}$ But this voice speaks with strength, trust, and freedom, indicting the fulfilment of Isaiah prophecy in himself (40, 2-3), fulfilment which, if understood correctly, speaks about The One that will come after him, The One who truly is Messiah.

To the insistences to find out from where did he get permission to baptize others, or what is the motivation of this baptism, John replies with gentleness and modesty, that he baptises with water, that is he does not offer the forgiveness of the sins, but, being witness to the glory of God, as one sent by Him (John 1, 16), he knows he is a path opener, a guide towards the spiritual baptism of Whom, although He is among them, they do not know Him yet, because He has not revealed Himself yet.

The footwear that John referred to, represent the incarnation of Christ, and the belt signify the bondage of the sins that he could not break, because the Saviour was without sin or guile, in contrast with the people who were confessing their sins at Jordan. The belt could also signify the way of the Saviour's incarnation, without any means to be broken or untied by humans. ${ }^{24} \mathrm{St}$. John Chrysostom remarks in this sense: "If the Jews wouldn't have heard anything about Jesus Christ, before they saw Him, if they would have received this great and wonderful confession only by seeing Him, the simplicity and poorness of His clothes would have diminished His glory. Jesus Christ was walking on the streets dressed simple and poorly so that all dared freely and with ease to approach Him and talk to Him". ${ }^{25}$

\section{THE BAPTISM WITH WATER}

The sober stature of the prophet enlightens at the river Jordan, electrifying his listeners hearts. He receives their confession of sins (Mt. 3,6), the concrete proof of their desire to get rid of the old human in them, subjected to sin and death, to be granted the baptism in the river Jordan as a seen sign of their renewal which must dominate their lives from now on. Everything happens in a simple mater, without any ceremony, which makes the humans gestures and their sincere expression more natural. The cleansing of sins, as the water washes the dirt from the body, or the clothes, does not happen, he himself confessing that the baptism of holy Spirit and fire (Luke 3,16) is needed for that. But for the people now this baptism with water is sufficient, because it offers them the feeling and the trust that they can change their lives, opposing sin, because they have become aware of their need to become closer to God, as a purpose and fulfilment of their lives. All of Palestine is roused by this emotional thought and many go to the river Jordan to receive the baptism of repentance.

\footnotetext{
${ }^{23}$ Sf. Teofilact al Bulgariei, op. cit., p. 39

${ }^{24}$ Ibidem, p. 42

${ }^{25}$ Sf. Ioan Gură de Aur, op. cit., p. 63
} 
The most intense moment of John the Baptist's activity is the granting of the repentance baptism to our Saviour Christ, event which happens according to Evangelist John, the second day of the inquiring visit of the Pharisees from Jerusalem (John 1, 29). This moment is presented by all Evangelists, but each of them with different details, which, put together in their natural order, provide a complete image of the event.

The Evangelist John mentions the proclamation of Jesus' messianism by John the Baptist, during their first public meeting, before the act of the baptism: "Here is the Lamb of God who takes away the sin of the world! This is he of whom I said, 'After me comes a man who ranks ahead of me because he was before me.' I myself did not know him; but I came baptizing with water for this reason, that he might be revealed to Israel" (John 1, 29-31).

The Evangelist Matthew completes the biblical narrative by presenting the dialogue that took place between them before the baptism: "John would have prevented him, saying, "I need to be baptized by you, and do you come to me?" But Jesus answered him, "Let it be so now; for it is proper for us in this way to fulfil all righteousness." Then he consented" (Mt. 3, 14-15). The Evangelists Mark and Luke present directly the baptism event, pointing out not the act itself but what significantly happened right after it: "And when Jesus had been baptized, just as he came up from the water, suddenly the heavens were opened to him and he saw the Spirit of God descending like a dove and alighting on him. And a voice from heaven said, 'This is my Son, the Beloved, with whom I am well pleased"' (Mt. 3, 16-17; Mark 1, 911). From the text's formulation, at Evangelist Mark we deduct that only Jesus sees the heavens open and the Spirit of God like a dove alighting on Him, which represents a gesture of investiture which fulfils the prophecies (Isaiah 11,$2 ; 42,1 ; 61,1){ }^{26}$ The voice from the heaven appears to be addressed to him directly, as a recognition and confirmation: "This is my Son, the Beloved, with whom I am well pleased" (Mark 1, 11).

Evangelist Luke, writing his Gospel for the "peoples",27, presents a few special aspects. The Saviour is baptised after all the people who came that day to John are baptised. The theophany happens when our Saviour was praying after the receipt of the baptism. The

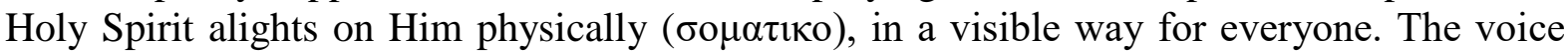
from heaven is heard confirming the Saviour's filiation in this unique posture, by the kenotic God. The words are the same as those from St. Evangelist Mark's Gospel (Luke 3, 21-22). "The recognition of Jesus as the Son announces the adoptive filiation of the believers, a participation to that of Jesus and a consequence of the Holy Spirit's grace (Gal. 4, 6)". ${ }^{28}$

This is the peak moment of the activity of John the Baptist and the fulfilment of his mission: the proclamation of Messiah before the Jewish people that was prepared to receive Him, the confession of John regarding Him, the confirmation of His divine filiation from the Father and John, along with the alighting of the Holy Spirit on Him. "The Son of God incarnated, although He did not need this rebirth through Baptism, because he was from the beginning born from the Spirit, accepts the Baptism for us humans, to be in this regard the first human who is baptised through water and Spirit. Through this He united the Spirit in Him in an actual way with the water which is also the support of life, this time of the life no longer subjected to death, as it is fully united with the Spirit. In this way Christ fulfilled forever all the justice through which He will cloth again all the humans who will believe."29

\footnotetext{
${ }^{26}$ Xavier Leon-Dufour, op. cit., p. 80

${ }^{27}$ Pr. prof. dr. Vasile Mihoc, Lect. dr. Daniel Mihoc, Pr. asist. Ioan Mihoc, op. cit., p. 85

${ }^{28}$ Xavier Leon-Dufour, op. cit., p. 80

${ }^{29}$ Pr. Prof. Dr. Dumitru Stăniloae, op. cit., p. 27
} 
With John's baptism also our Saviour was baptised, not because He needed it to be cleaned of sins, He being the God-Human, but to underline the importance and the work of the Baptism which He will establish and to reveal God to the world, The One in three folded Persons, in Whose name we should also be baptised. "The Saviour received the first the Holy Spirit, although He Himself was the giver of the Spirit, so that this dignity to come to us through Him and so we would have gift of bearing the Holy Spirit". ${ }^{31}$

The Saviour does as a human an act of humbleness, of submission towards the divine will, receiving the baptism of redemption which symbolizes the cleansing of sins. The dove is the most appropriate bird (the only one used as a purification sacrifice for the poor ones at the temple: Lev. 1, 14, Nr. 6, 10), to represent a loving, patient and receptive to the humans' sorrows God. ${ }^{32}$ The Evangelist John continues the biblical narrative by mentioning the reaction of John the Baptist: "And John testified, 'I saw the Spirit descending from heaven like a dove, and it remained on him. I myself did not know him, but the one who sent me to baptize with water said to me, 'He on whom you see the Spirit descend and remain is the one who baptizes with the Holy Spirit.' And I myself have seen and have testified that this is the Son of God"' (John 1, 32-34).

Truly John the Baptist fulfils his mission by showing everyone who is The One Who he has announced since then: The One who would bring salvation to all humans. This when the Saviour exits anonymity and shows Himself to the people of Israel through the Father's confirmation, is chronologically framed in the life of our Saviour by Evangelist Luke. Our Saviour had "around thirty years" (Luke 3, 23), which indicates also the age of John the Baptist at that time, who was older by six months than our Saviour.

John the Baptist did not know our Saviour, because he lived in the desert, but when He came to the river Jordan, by seeing Him, he knew in spirit that that One is the One who he had announced, ${ }^{33}$ as he also recognised Him when he moved in the womb of Elisabeth (Luke $1,41)$. He points out indirectly the lack of sin of our Saviour, by refusing initially to baptise Him, because He did not need to go through this act. Our Saviour wishes however to be baptised for the fulfilment of the future significances, knowing that the time will also come when His glory will be no longer hidden. He is referring to the justice that needs to be fulfilled, which is the Law, because the human nature was cursed because it could not fulfil the Law. "So, because I fulfilled the others of the Law and all that I am lacking is to get baptised, do that too, I will release the human nature from the curse because that is what fits $M e$ ". ${ }^{34}$ St. John Chrysostom notes that "Jesus Christ did not need John's baptism, nor another one, but the Baptism needed literary the power of Jesus Christ, because what it still lacked was the supreme good, the grace of the Holy Spirit". ${ }^{35}$

St. John the Baptist did not have the power to offer the Holy Spirit through his baptism. Those who would get baptised by him did not know that the Holy Spirit exists (Acts 19, 2). As we observe in the John's Gospel, the Forerunner insists on the fact that he did not know our Saviour. St. John Chrysostom says that the Forerunner does in this way so that no one can consider that he makes such a confession about Him based on their kinship. ${ }^{36} \mathrm{He}$

\footnotetext{
${ }^{30}$ Pr. Prof. Dr. Dumitru Radu, op. cit., p. 514

${ }^{31}$ Sf. Chiril al Alexandriei, op. cit., p. 35

${ }^{32}$ Xavier Leon-Dufour, op. cit., p. 566

${ }^{33}$ Sf. Ioan Gură de Aur, op. cit., p. 85

${ }^{34}$ Sf. Teofilact al Bulgariei, op. cit., p. 27

${ }^{35}$ Sf. Ioan Gură de Aur, op. cit., p. 84

${ }^{36}$ Ibidem
} 
confessed about Jesus from Nazareth that $\mathrm{He}$ is the Messiah prophesized by the prophets, even to his own apprentices (John 1,35-36), indicating in this way The One that full of humbleness was about to sacrifice Himself for everyone's sins.

The mission of the Forerunner was fulfilled, as he also admits: "but I came baptizing with water for this reason, that he might be revealed to Israel" (John 1,31). The well-known personality of the Forerunner represents a guarantee for his claims regarding our Saviour Christ. That One was going to grow, while he was going to shrink (John 3, 30), that is why we see that the Forerunner announces and confesses about Him to everyone. A part of his apprentices will follow now the true Teacher, God's Lamb, the Saviour of the world. He is the Groom in Who's hand the friend of the Groom (St. John the Baptist), brings the hand of His bride, His Church (Eph. 5, 23-29), that is the souls of the humans convinced by his sermon and the example of his life. ${ }^{37}$

\section{GOD'S CONFESSION ABOUT JOHN THE BAPTIST}

A special event in the life of our Saviour is the visit of John's apprentices, in the time when their teacher was in the Herod's prison. Hearing about Jesus' deeds, John sends to Him two of his apprentices asking Him: "'Are you the one who is to come, or are we to wait for another?' Jesus answered them, 'Go and tell John what you hear and see: the blind receive their sight, the lame walk, the lepers are cleansed, the deaf hear, the dead are raised, and the poor have good news brought to them. And blessed is anyone who takes no offense at me" (Mt. 11, 4-6; Luke 7, 22-23). "Jesus had just then cured many people of diseases, plagues, and evil spirits, and had given sight to many who were blind" (Luke 7, 20-21).

This moment arouses certain reasonings regarding what needs to be understood regarding John and his apprentices. Disbelief, impatience, or moment of conviction? St. John Chrysostom offers maybe the most appropriate and acceptable explanation regarding such a question, that stirred contradictory hypotheses over time. ${ }^{38}$ St. John the Baptist confines to his apprentices a pretext doubt, so that his apprentices who were fine with their teacher's shrinking, seeing our Saviour miracles, to understand themselves that Jesus is the Messiah, and so, to follow His teachings from that moment forward. The question asked by his apprentices would express actually a misunderstanding about our Saviour, and that is that $\mathrm{He}$ appears as the Lamb that lifts the sins of the world and not as a vigilante God, as John the Baptist publicly announced Him, ready to snatch and punish all unfaithfulness. ${ }^{39}$

Surely John knew about the sacrificial mission of our Saviour, because he named Him "the Lamb of God" at Jordan (John 1,36), which naturally refers to the daily sacrifice of lambs on the temple's altar as a holocaust. ${ }^{40}$ And also our Saviour answer confirms Him as Lamb, as God emptied of His glory (Phil. 2, 7-8), incarnated due to His love for the human, to straighten him from the inside, so that anyone who believes in Him will not perish, but will have eternal life: "For God so loved the world that he gave his only Son, so that everyone who believes in him may not perish but may have eternal life" (John 3, 16-17). He will also

\footnotetext{
37 Ibidem, p. 88

${ }^{38}$ St. Theofilact of Bulgaria, commentating this text, reminded also some's opinion which tied the question "Are the one who is to come?" to the possibility of our Saviour descent all the way to hell, therefore willing to say "Are you the one who also comes even in hell?". This perspective is also wrong, because the Forerunner "being greater than the prophets, knew about Christ's crucifixion and His descent to hell". Sf. Teofilact al Bulgariei, op. cit., p. 64

${ }^{39}$ Noul Testament, comentat de Î.P.S. Bartolomeu Anania, p. 20

${ }^{40}$ Pr. Prof. Dr. Dumitru Abrudan, Diac. Prof. Dr. Emilian Cornițescu, op. cit., p. 266-267
} 
come as a Judge, when He will decide to end all times (John 5, 22), judging us as being one of us, the Son of Man. Therefore, St. John the Baptist could not doubt the messianism of our Saviour after he saw with his own eyes the alight of the Holy Spirit on Him at the river Jordan, but his apprentices, being to attached to him to understand the reality, were opposed to our Saviour and His apprentices (John 3, 25-36).

For those who ask Him, our Saviour demonstrates on the spot His divine power (Luke 7, 20-21), through the deeds that were prophesized in the Old Testament and characterised Messiah activity, then He freely quotes from these prophets (Mt. 11, 6; Luke 7, 22). The texts to which $\mathrm{He}$ is referring to are the following:

1. Isaiah 35, 5: "Then the eyes of the blind shall be opened, and the ears of the deaf unstopped";

2. Isaiah 61, 1: "he has sent me to bring good news to the oppressed, to bind up the brokenhearted, to proclaim liberty to the captives, and release to the prisoners";

3. Isaiah 29, 18: "On that day the deaf shall hear the words of the scroll, and out of their gloom and darkness the eyes of the blind shall see";

4. Ezekiel (chap. 37) and Daniel $(12,2)$ speak about the resurrection of the dead as a specific messianic act.

Our Saviour's demonstration ends with a small reprimand for the general lack of faith in Him, not just that of John's apprentices: "blessed is anyone who takes no offense at me" (Luke 7, 23). From here we understand that people cannot be forced to understand reality, because the personal sins darken the eyes of the mind and only through effort the human can succeed. Many times our Saviour says: "Whoever has ears, let him hear" (Mt. 11, 15), that is whoever is not satisfied with a superficial explanation, but focuses his spirit and mind, he who is cleansed of sins, that one will be able to understand the divine truth. This is actually the human's obligation. As the messianic prophecies were fulfilling in front of everyone, then, He who does all that is inevitably the Messiah! Such a conclusion should have been deducted by everyone.

After the departure of John's apprentices, so that the witnesses would not form a wrong idea, the Saviour admits in front of everyone St. John the Baptist merits and this is the key point of all the appreciations of the last prophet of the Old Testament. Jesus says that John is not like human who has an unstable faith, changing it like a reed that bends at the slightest bow of the wind (Mt. 11, 7-8). His steadfastness is founded on the austere life that he has, which lacks soft clothes, offers and pleasures that weaken the soul. His steadfastness towards the truth and justice is observed also in the fact that now John is imprisoned because he dared to say the truth and to condemn the violence, no matter the consequences. ${ }^{41}$

"What then did you go out to see? A prophet? Yes, I tell you, and more than a prophet" (Mt. 11, 9). These words underline the fact that the prophetic mission of John indicate the fundament of his steadfastness. He is a man truly inspired by God, His "mouth" towards the humans, ${ }^{42}$ a prophet who was also announced four centuries earlier by another prophet, Malachi $(3,1)$. He is more than a prophet, because, unlike the others, he did not just announce the Messiah, he also saw Him, presenting Him thus to the world. Even Malachi's prophecy names him the "angel" of God, indicating his purpose as an emissary of the divine commands to the humans, ${ }^{43}$ but also the pure life that he lived, without sin, truly angelic.

\footnotetext{
${ }^{41}$ Xavier Leon-Dufour, op. cit., p. 554

${ }^{42}$ This is a popular projection about the prophets of the Old Testament. XXX, Studiul Vechiului Testament, pentru Institutele teologice, p. 215

${ }^{43}$ Pr. Dr. Ioan Mircea, op. cit., p. 259
} 
The mission granted to the Forerunner encompassed the spiritual preparation of the humans for the greeting of Messiah, the baptism of redemption for the awareness of the sinful state, ${ }^{44}$ the consequent and competent confession of the messianism of Jesus Christ, the announcing of the imminent establishment of the kingdom of heavens. The redemption arosed from John's sermons would naturally attract the forgives of the sins by our Saviour. ${ }^{45}$ And, to be more convincing, our Saviour recognises the following truth: St. John is the greatest man born from women, but the smallest one in the kingdom of heavens (Mt. 11, 11). This comparison does not include our Saviour too, because He is not born from a woman, that is through a natural way, having an earthly father, but He is born before the time by the Father (John 1, 1-5) and incarnated Himself through Virgin Mary.

John is born from a woman, through a natural way, bearing the guilt of the ancestral $\sin (\mathrm{Job} 15,14 ; 25,4)$, but he is "the corollary and the end of the Old Testament, the one who announces and prepares the kingdom of heavens, but he does not start it. He continues to be the bridge between what it was and what will be" ${ }^{\text {"46 }}$, bridge which, being organically tied to what it was, humanity without the saving grace gained from the Baptism, determines that the greatest one under the Law to be the smallest one under the grace. The Law came through Moses, but the grace and truth through Jesus Christ (John 1, 17). As conclusion, St. John is greater than all the prophets of the Old Testament, because those also prophesized about Messiah Who was about to come, while he is also contemporary and forerunner.

Our Saviour continues: "From the days of John the Baptist until now the kingdom of heaven has suffered violence, and the violent take it by force. For all the prophets and the law prophesied until John came; and if you are willing to accept it, he is Elijah who is to come" (Mt. 11, 12-14). So, the kingdom of heavens is gained through struggle, a struggle with one's own weaknesses and vices, but also the struggle with the temptations offered by the devil. The one who insists, persevere and take it by "assault", that is they dedicate themselves entirely to this action, those are also the ones who conquer it. St. Ap. Paul said: "So I do not run (for the prize) aimlessly, nor do I box as though beating the air; but I punish my body and enslave it, so that after proclaiming to others I myself should not be disqualified" (I Cor. 9, 26-27).

St. John ends the cycle of the prophets of the Old Testament, but also the period when the Jews were guiding themselves by the Law, because our Saviour Christ is the fulfilment and the end of the Law. The prophets announced and the sacrifices prefigurated Messiah, but now all are fulfilled in the person of the Son of God, Who incarnated Himself and offers a new perspective to the human. The Messiah has a Forerunner whom was known by all those around our Saviour and who deserves all the consideration and admiration, being associated by our Saviour with the prophet Elijah, whose coming before the great and frightening Day of the Lord was prophesized by also Malachi $(3,23-24)$. He would have the role to turn around the hearths of the parents towards their sons and the hearths of the sons towards their parents, so that God would not come and strike the country with course. This role was fulfilled by St. John the Baptist himself through divine command.

The Jews, not understanding the humble coming of Jesus from Nazareth, expected a triumphal coming of the Messiah, associated with the judgment of the whole world (Isaiah 3, 13-14; Joel 2, 1-14). In their perspective, they believed that the prophet Elijah must first come to prepare those needed for such a kingdom, but such an emissary had been sent in the

\footnotetext{
${ }^{44}$ Xavier Leon-Dufour, op. cit., p. 80

${ }^{45}$ Sf. Teofilact al Bulgariei, op. cit., p. 65

${ }^{46}$ Noul Testament, comentat de Î.P.S. Bartolomeu Anania, p. 20
} 
person of St. John the Baptist (Mt. 11, 14). In spite of his mission of overwhelming importance, the Jews judged him arbitrarily, humanely, evaluating him based on his way of living, a hyperbolic person who seeks exaltation by isolation in the desert, precisely because he has a demon: "For John came neither eating not drinking, and they say, 'He has a demon"'(Mt. 11, 18). And the Son of Man, Who behaves like a normal man, on the contrary, they considered him insatiable: "the Son of Man came eating and drinking, and they say, 'Look, a glutton and a drunkard, a friend of tax collectors and sinners!' Yet wisdom is vindicated by her deeds" (Mt. 11, 19).

Beyond people's opinions and appreciations, God's wisdom proves its validity over time, through its deeds, effects and consequences. The Jews are unstable in their appreciation, like the children who do not like the songs of mourning, nor those of the whistle, that is, neither John's harshness, nor the freedom and joy full of the Saviour's love. ${ }^{47}$

St. Theophilact offers yet another reason why the Pharisees and Scholars denied Jesus's messianism. Taking as a pretext the prophecy of Malachi (3:23), which announced the coming of Elijah before the coming of the Messiah, they did not know that there are two comings of Christ. The first coming - a humble one, to which John was a forerunner, and the second coming in glory, to judge the world. Before this end, Elijah will come, "who will put all in place", which means that all the Jews who will be obedient will return to the faith in Messiah. ${ }^{48}$

The association between St. John the Baptist and the Prophet Elijah will be repeated by the Saviour also on the night of the Transfiguration, on mount Tabor (Mt. 17, 1-13). After the wonderful event, in which they were able to observe the prophet Elijah himself, Peter, James and John, descending down the mountain with our Saviour, they asked Him: "'Why, then, do the scribes say that Elijah must come first?' He replied, 'Elijah is indeed coming and will restore all things; but I tell you that Elijah has already come, and they did not recognize him, but they did to him whatever they pleased. So also the Son of Man is about to suffer at their hands.' Then the disciples understood that he was speaking to them about John the Baptist" (Mt. 17, 10-13). This occasion again emphasizes the spiritual stature of the last prophet of the Old Testament, a man devoted to the service of God until his own death. A narrow-mindness clouded by sin could not comprehend the truth about the mission which St. John fulfilled. For this reason, the Jews judged him in various ways, from a superficial judgement to a total disregard, all the way to its killing, a crime to which no one from that time opposed, which will draw the fault over all. Saint John's sermon would condemn the spiritual void of the Jewish people, the lack of understanding the true meaning of the law of Moses, dry ritualism and the entire moral decline. In this preaching for faith, justice and truth, wishing to prepare the souls of the people for the kingdom of heavens which was about to be founded, without looking at the face of man, St. John also criticized the tetrarch Herod who, besides other evil acts, had taken as his wife Irodiada, the wife of his brother Philip (4 $\mathrm{BC}-34 \mathrm{AD}),{ }^{49}$ one of the sons of Herod the Great, the tetrarch of Ituri and of Trachonitis, Gaulanida, Auranida and Batana (Luke 3, 1). ${ }^{50}$ This marriage did not fit the requirements of the Levira, but was an adultery, setting a bad example for the morality of the people. Due to the sustained reproaches of St. John the Baptist, who accused him openly before the people and undermined his authority and, listening only to his wife's intrigues, who hated John and

\footnotetext{
${ }^{47}$ Sf. Teofilact al Bulgariei, op. cit., p. 67

${ }^{48}$ Ibidem, p. 105

${ }^{49}$ Pr. prof. dr. Vasile Mihoc, Lect. dr. Daniel Mihoc, Pr. asist. Ioan Mihoc, op. cit., p. 22

${ }^{50}$ Pr. Dr. Ioan Mircea, op. cit., p. 234
} 
wished his death, Herod imprisons him, even though he acknowledged in his hearth that he is right (Mt. 14, 5; Luke 3, 19-20; Mark 6, 17-20).

The occasion for the murder came up at a good moment, on the birthday of the tetrarch Herod, celebrated with his governors, the captains of the army and the eminent ones from Galilee (Mark 6, 21), in the city of Macherus, located two leagues from the Asphalt Lake (Dead Sea), ${ }^{51}$ near the border with Arabia, with whose king, Aretas, was at war with. ${ }^{52}$ The dance of Salome, the drunkenness of the drinks, the reckless promise before the witnesses, all these signs of moral decadence together led together to the beheading of John the Baptist (Mt. 14, 3-11; Mark 6, 17-28). St. Theophilact makes the following comparison: "Herod represents the Jewish people who took a woman, that is, the deceitful and unbridled glory, whose daughter dances even now at the Jews. Her deceitful dance is the knowledge of the Scriptures, because they deceive themselves by believing that they can know the Scriptures, which is not true, because they cut off John's head, which is the word of the prophecy, and the Head of the prophecy, that is, Christ, they did not receive. Therefore, though they have the prophetic word, this is without the Head, that is, without Christ". ${ }^{53}$

\section{THE LAST PROPHET OF THE OLD TESTAMENT'S REVELATION}

St. John the Baptist had to close a stage of the supernatural revelation. The Forerunner was not only prophesied by some prophets of the Old Testament, but, not at all coincidental, resembles some of them, both in the spiritual stature and in the repetition of certain fundamental themes from the prophetic "repertoire", which are concisely resumed, but expressively, because they are still valid.

At St. John the Baptist we do not find the theme of idolatry so vehement in some preexilic prophets (Isaiah 1, 21; Jeremiah 3, 1-13), but it contains the fundamental aspect of the altered relationship between the human and God, which consists in the existence of sin, more or less aware of them. This is why his fundamental theme is repentance, as a need for the cleansing of souls through awareness, regret, soul pain, a decision of rectification and concrete gesture in confessing and casting out sins, to receive the concrete act of cleansing and renewal - baptism with water.

St. John the Baptist resembles best the prophet Amos of the eighth century $\mathrm{BC},{ }^{54}$ under the following aspects: preaching sobriety; whipping the vices and announcing the punishments. ${ }^{55}$ Indeed, we distinguish a certain sobriety in the prophetic stature of St. John, in many respects, starting with the first impression he creates. His clothing is of a poor man, but also of a penitent, a harsh cloth which carves the skin of the body in an attitude of whipping the instincts and sinful thoughts, which spring from laxity caused by the benefits of life. The sobriety is also expressed by his food, offered by God from nature. Honey and locusts mean unimproved food through variety, preparation, heating, or seasoning that enchants the taste. It is a simple, natural, common food, but sufficient for the man preoccupied with spirituality. And, as a result of these two aspects, the words of the Forerunner are full of sobriety, both through concision and message. "Repent!" he called continually, for a time, in the desert of Judea, emphasizing this fundamental spiritual need for the salvation of humans.

\footnotetext{
${ }^{51}$ Protos Olivian Bindiu, Cuvânt la nașterea Sf. Ioan Botezătorul, în Glasul Bisericii, nr. 3, 1988, p. 33

${ }^{52}$ Pr. prof. dr. Vasile Mihoc, Lect. dr. Daniel Mihoc, Pr. asist. Ioan Mihoc, op. cit., p. 20

${ }^{53}$ Sf. Teofilact al Bulgariei, op. cit., p. 211

${ }^{54}$ Studiul Vechiului Testament, pentru Institutele teologice, p. 269

55 Ibidem, p. 272
} 
The theme of repentance is also found in the missionary program of other prophets, with certain nuances. The prophet Ezekiel points out the need for repentance as an exhortation from Yahweh to his people, the return from unrighteousness by discarding unbelief $(18,30)$. Hosea urges the people to find appropriate prayers for the expression of repentance to replace the blood sacrifices with the sincerity of the heart $(14,13)$. And Joel warns that only repentance could bring a blessing on the descendants, as an offering and a sacrifice before the Lord $(2,14)$.

Repentance requires concrete deeds (Jonah 3, 10), with the confession of sin (Zechariah 1,6), being a true return from sin to the true God (Jude 5, 19). Repentance wipes away sin by fulfilling the will of God (Ezra 10, 11), ensuring steadfastness in his ways (2 Samuel 22, 22). God, in His wisdom and in the desire to continually pour His mercy upon the humans, does not hasten to punish the mistakes of the humans, but gives them time, approaching "slowly" toward them, "giving them space for repentance" (Proverbs 12, 10).

And as an effervescent expression of repentance we can observe the example of David (2 Samuel 12, 16), or the deep prayer of Manasseh $(1,8)$. The theme of repentance in the midst of judgment also plays an important role in the prayer of King Solomon, ${ }^{56}$ at the sanctification of the temple (1 Kings 8, 33-53).

The profound devotion of the Forerunner to his mission can be found in the lives of other prophets. Isaiah was killed by the command of King Manasseh, according to a tradition, through the cutting with the saw. ${ }^{57}$ Jeremiah is the concrete example of the martyr prophet, who upholds the cause of his mission at any cost, resorting insistently to symbolic acts to persuade the audience (chap. 18-20), beyond the force of his word. He struggles with the opposition of the false prophets, with the diplomatic wishes of the kings of his time and with the divisive from God idolatry, intertwined with the moral neglect of the people. A powerless and dramatic assistance to a disaster, he himself dying, according to a rabbinical variant, from the hand of an idolatrous Jew in Egypt. ${ }^{58}$

The devotion of the prophetic cause, the complete dedication in the mission, regardless of the reactions of the people, or consequences, is also encountered in the mission finally accepted by Iona, at the risk of his own life, in the midst of the Assyrian unbelievers $(3,3-10)$. And the obedience of the faithful human to God, especially in assuming the mission to which he is called, is best expressed by the prophet Amos: "If the lion roars, who will not be afraid? And if the Lord speaks, who will not prophesize?"(3, 8).

John the Baptist also resembles Elijah the Tishvite in several respects. He invoked fire from heaven to prove the presence of the true God in creation (1 Kings 18, 36-39), St. John showed the world our Saviour Christ himself, the Son of God incarnate, The One who was to baptize with fire (Luke 3, 16). Both of them had to deal with the unbelief and vicious abandonment of the Jews from the demands of their vital communion with God, wearing approximately the same clothing and creating the same image before the audience. ${ }^{59}$ They both live the mystery of human's encounter with God in the superlative way, within the limits of human endurance and dialogue with Him (1 Kings 19, 10). Both face the opposition of the representatives of the world power who do not support criticism and react harshly, trying to eliminate the opponent (1 Kings 19, 1-3; Mt. 14, 1-11).

\footnotetext{
${ }^{56}$ Introducere în studiul Vechiului Testament, Pentateuhul și cărțile istorice, Ed. Casa cărții, Oradea, 2016, p. 392

${ }^{57}$ Studiul Vechiului Testament, pentru Institutele teologice, p. 223

${ }^{58}$ Ibidem, p. 235

${ }^{59}$ Introducere în studiul Vechiului Testament, Pentateuhul și cărțile istorice, p. 393
} 


\section{CONCLUSIONS}

The Saviour's statement: "there has not risen from among those born of women any greater than John the Baptist" (Mt. 11, 11), expresses a great truth combined with a feeling of admiration and gratitude for the one who was a very special man, an angel in the body, a prophet who has completely fulfilled his entrusted mission. The forerunner came like a flame before the sun, being foretold in the Old Law by the unextinguished flame burning in the first part of the tent. ${ }^{60}$ The Jews enjoyed his presence and activity for a short time, and then left him. That is why the Saviour also says of him, "He was a burning and shining lamp, and you were willing to rejoice for a while in his light" (John 5, 35).

Like the One who incarnated Himself for our salvation, the birth and life of Saint John the Baptist were arranged by God in His great wisdom, "For who has known the mind of the Lord? Or who has been his counselor?" (Rom. 11,34). The divine providence was received greatly in the soul and life of this man, giving us a sublime example of faith and devotion in the person of whom was to be called in the history of the Church, the Forerunner and the Baptizer of the Lord.

\section{BIBLIOGRAPHY:}

[1] Introducere în studiul Vechiului Testament, Pentateuhul și cărțile istorice (Introduction to the Old Testament. The Pentateuch and the historical books), Ed. Casa cărții, Oradea, 2016

[2] Noul Testament (New Testament), comentat de Î.P.S. Bartolomeu Anania

[3] Studiul Vechiului Testament, pentru Institutele teologice (The Study of New Testament for theological institutions), Ed. IBMBOR, București, 1983

[4] Abrudan, Pr. Prof. Dr. Dumitru, Cornițescu, Diac. Prof. Dr. Emilian, Arheologie biblică (Biblical Archaeology), Ed. IBMBOR, București, 1994

[5] Bindiu, Protos Olivian, Cuvânt la nașterea Sf. Ioan Botezătorul (Sermon at the birth of St. John the Baptist), în Glasul Bisericii, nr. 3, 1988

[6] Bria, Pr. Prof. Dr. Ioan, Dicționar de Teologie Ortodoxă (Dictionary of Orthodox Theology), Ed. IBMBOR, București, 1994

[7] Chiril, Sf. al Alexandriei, Comentar la evanghelia după Luca (Commentary at Luke's Gospel), Ed. Pelerinul Român, Oradea, 1998

[8] Dufour, Xavier Leon-, Vocabular de Teologie Biblică (Vocabulary of Biblical Theology), Ed. Arhiepiscopiei Romano-Catolice de București, 2001

[9] Ioan, Sf. Gură de Aur, Comentar la Evanghelia de la Ioan (Commentary at John's Gospel), Ed. Pelerinul Român, Oradea, 1997

[10]Mihoc, Pr. prof. dr. Vasile, Mihoc, Lect. dr. Daniel, Mihoc, Pr. asist. Ioan, Introducere în studiul Noului Testament, Curs pentru anul I (Introduction to the study of New Testament. $1^{\text {st }}$ year Course), Sibiu, 2007

[11]Mircea, Pr. Dr. Ioan, Dicționar al Noului Testament (Dictionary of New Testament), Ed. IBMBOR, București, 1995

[12]Radu, Pr. Prof. Dr. Dumitru, Indrumări misionare (Missionary guidance), Ed. IBMBOR, București, 1986

[13] Stăniloae, Pr. Prof. Dr. Dumitru, Teologia Dogmatică Ortodoxă (Orthodox Dogmatic Theoogy), Vol. III, Ed. IBMBOR, București, 1997

[14]Teofilact, Sf. al Bulgariei, Tâlcuirea Sf. Evanghelii de la Matei și Marcu (Commentary at Matthew's and Mark's Gospels), Ed. Sofia, 1998

\footnotetext{
${ }^{60}$ Sf. Chiril al Alexandriei, op. cit., p. 12
} 